\title{
BLACK SEA ECONOMIC CO-OPERATION (BSEC)
}

\author{
A NEW REGIONAL INTEGRATION PROJECT*
}

\author{
Dr. Muzaffer DARTAN**
}

\section{Introduction}

The process of regional integration is gradually gaining importance in the world. Countries having common interests and harmonious economic structures in a geographically congenial area tend to set up regional economic and commercial associations. This is so because the integrity of markets entails an efficient usage of factors of production (labour, capital and resources), in other words, it increases the production, trade and prosperity of the area by also enhancing competitiveness in the world-trade. There are several models of regional economic and commercial arrangements in the world today. Particularly three economic blocks have affected the world economy: namely, European Community, North American Free Trade Area and Asian Pacific Economic Co-operation.

The European Community (EC) as we know it today is a monument to the dedication of its founders. EC is an advanced form of multisectoral integration, its competence extending to the economy, industry, politics, citizens' rights and aspects of foreign policy. The Treaty of Paris establishing the European Coal and Steel Community (1951), the Treaties of Rome establishing the European Economic Community and the European Atomic Energy Community (1957), the Single European Act (1986) and the Maastricht Treaty (1992) form the constitutional basis of West European Unity binding its member states more firmly than any other conventional agreement between sovereign states'.

The member countries of EC include: Belgium, France, Germany, Italy, Lux-

- This article is a short summary of a research on "Black Sea Economic Co-operation Projecr" which will be published as a book soon.

* Assistant professor of economics at EC Institute of University of Marmara, Istanbul.

1 EC-Commission, 1992, "Treaty on European Union" Luxembourg. 
embourg, the Netherlands (founder members), Denmark, Ireland, the United Kingdom (1973), Greece (1981) and Spain and Portugal (1986). EC has a population of 346 million. Its external exports (excluding members trade with each other) amounted to more than ECU 430 billion in 1992. The Twelve accounted for $15 \%$ of world exports compared with $12 \%$ for the United States and $9 \%$ for Japan ${ }^{2}$. Moreover the EC signed the Agreement on European Economic Area (EEA) in 1991 with the states of the EFTA (European Free Trade Area), set up in 1959. The member states of the EFTA include: Austria, Finland, Iceland, Norway, Sweden, Switzerland and Lichtenstein. The EEA comprises 19 countries that have a population of 380 million $^{3}$. In the period 1972-1986 trade between the EC and EFTA has quintupled and has reached a level of 165 billion ECU4.

In 1992, North America Free Trade Agreement (NAFTA) was signed by USA, Canada and Mexico with the aim of establishing a common market. In the future, it is anticipated to cover all North and South America as one continent. The three member states of NAFTA intend to remove all trade barriers between themselves and to provide free circulation of capital in 15 years, starting from 1994. In NAFTA the free movement of labour has been excluded, since the Mexican labourers would be massively moving to the two other member states. Moreover, certain "sensitive sectors" have been reserved to the member states ${ }^{5}$. Already before NAFTA came into existence, the commercial relations of those three countries had developed. For example, Canada is the greatest trade partner of USA. In the Mexican case, she is the third biggest country having highest trade volume in the USA after Canada and Japan. The NAFTA is expected to create a huge open market with over 360 million consumers and over $\$ 6$ trillion annualy in goods and servics ${ }^{6}$.

A similar regional integration is being created under the leadership of Japan, that is, the Asian Pacific Region. According to an OECD report, this region will develop as an economic homogenous area by 2000 . The report anticipates that, by 2010 the Asian Pasific Region will provide one third of the world production. By the year of 2040, it is estimated that this region will cover half of the world trade. The same report also claims that, the annual rate of growth in Asian Pasific Region is

2 EC-Commission, 1993, "Europe in a Changing World - the External Relations of the European Community", Luxembourg, p. 7.

3 EC-Commission, 1992, “Europe in Ten Lessons”, Luxembourg, p. 27.

4 De Lange, H., 1988, "Taking Stock of the EC-EFTA Dialogue", in Jamar, j. and Wallace, H. (eds.), EEC.EFTA More Than Just Good Friends?, Proceedings of the Symposium organized by the College of Europe, 30 June - 2 July 1988, Bruges, p. 311.

5 Harrison, D. and Weigel, K.G., 1993, "Customs Provisions and Rules of Origin under the NAFTA", The International Lawyer, vol. 27, No. 3, pp. 647-669.

6 Bello, J.H. and Holmer, A.F., 1993, "The North American Free Trade Agreement (NAFTA)", The international Lawyer, vol. 27, No. 3, p. 591. 
reaching between $5-6 \%$. By comparison the growth rate of North America, is estimated at $2,5 \%$, because of the low rate of increase in the US production. On the other hand, EC countries having a high rate unemployment level and social problems, cannot do better?.

Turning back to the Asian Pasific Region, where Japan is the leader, she is dealing with many economic problems: There are apart from Japan, other groups of states which could be divided into two subgroups: The "Four Dragons of Eastern Asia" i.e. Taiwan, Hong Kong, Singapour and South Korea; and the countries of a second league in industrialization, like Malasia, Indonesia, Philippines and Thailand. On the other hand, China with 1,17 billion potential consumers is drawing attention with her fast growth; in other words, China is one of the powerful countries in the Far East with her potential to rival Japan when she has coped with her own political troubles and passed into market economy.

The importance of regional integration has been recently appreciated by countries that are not members of any regional grouping. They are now endeavouring to form or join an economic cooperation project. The BSEC organization can be seen as a product of this frame of mind. It is common ground that, the world has experienced radical changes in the 1980's, like the dissolution of the Soviet Union and the liberation of the Eastern European countries that followed the collapse of the socialist system and of the bipolar world order, established after the World War II. The USA in the West, the Soviet Union in the East had become the power centres of this bipolar world and between themselves had created rivalry in almost every issue. Through the collapse of socialist system, the globalization of world in the direction of multi-purpose regional international integration had started a restructuring process. Within this process economic blocks are taking the place of political blocks.

The most important factor that leads to the restructuring process is the preference of the Soviet Union and the Eastern European Countries to move to market economy and pluralist democracy. In other words, the process of market economy and liberalization led Soviet Union and Eastern European Countries to evaluate the fact that economic potential of a region should be realized through the co-operation with other countries. Therefore, those countries understood the need for integration in the changing world order which cannot be achieved only by their own endeavors. As a result, economic blocks came into existence and, by gradually gaining importance in the world, they reflect this new process. One of these is the BSEC Project, composed of primarely the former socialist countries, which is still in a formative stage.

7 Istanbul Ticaret, 1992, “Asya-Pasifik Bölgesi Dünya Ekonomisinin Merkezi Olmaya Aday”, 14 August, p. 2.

8 See Bollard, A. and Mayes, D., 1992, Regionalism and the Pacific Rim, in Journal of Common Market Studies, vol. XXX, No. 2, pp. 204-205. 


\section{BSEC Project - A New Model?}

BSEC Project can be identified with existing traditional ties among member states, geographical proximity and complementary economies. It is going to come into existence on the basis of co-operation in market economy, with the object of integrating with world economy. In the light of these premises the question arises what kind of regional economic co-operation should BSEC project suggest? To be able to answer, we shall consider now the existing models of regional economic co-operation.

\subsection{Free Trade Area}

As a free trade area the BSEC Project was considered as a final goal but, in fact, the object is the economic integration implying independent trade policies vis a' vis third countries. Therefore, it will lead to the elimination of both quantitative restrictions and custom tariffs. In the structure of free trade area, however member states are capable of preserving their own economies vis a' vis the third countries as they wish, because there is no obligation of imposing a common custom tariff against third countries. The aim of free trade area is to promote the trade in goods and services produced or supplied by member states, and to remove restrictive and prohibitive measures to make the movement of goods and services easy for establishing a common market. Others factors of production are not subject to free circulation among member states as is the case of EFTA and LAFTA ${ }^{9}$.

\subsection{Customs Union}

Customs union, being one of the stages of economic integration, purports to promote foreign trade by liberalizing it between the member states, in other words, member states set up a customs union by removing customs tariffs, quotas and other restrictive measures and by accepting a common customs tariff in trade with nonmember states ${ }^{10}$.

\subsection{Common Market}

Common market, being the further stage of economic integration does not only work towards integration of trade in goods and services, but it also provides the integration of market in other factors of production, in other words, countries establishing a common market remove the custom tarififs, quantitative restrictions and 
other restrictive measures in trade between themselves and impose a common customs tariff in trade with non-member states. Furthermore member states accept free movement of labour and of capital between themselves. One of the succesfull models for the realization of a common market is the EC which has liberalized foreign trade and movements of factors of production at home in large scale and has imposed a common commercial policy in respect of non-member states 11 .

\subsection{Economic Union}

It is the furthest stage of economic integration regulating the free movements of goods, of services, and of factors of production and also promoting monetary, fiscal and social policies as well as policy of competition agreement between its members ${ }^{12}$. The Maastricht Treaty signed by EC countries, is an example of the economic union.

Summarizing what we have said so far, it is clear that a proper distinction separating the stages of economic integration is hard to make. Taking the various characteristics of economic integrations into account by way of distinction, the first three stages are concerned with market integration, but the last step shall be for the realization of both economic and social integration.

In the light of the aforesaid, we shall attempt an evaluation of the BSEC Project as follows:

In the first official negotiations on BSEC Project, Turkey was proposing to establish a free trade area among the Black Sea countries as a goal of cooperation, whereas in the last draft of the BSEC Declaration, the area is proclaimed not only as a free trade area but also as the first stage of the economic integration, the member states being free to determine their own foreign trade policy by removing all trade barriers. Thus it is a flexible co-operation that differs from free trade area, customs union, common market and economic unions. Therefore, there is no free trade area proposed in the BSEC Declaration, but there is an indication of economic cooperation in the text of this initiative aiming at international economic integration.

The reason for proposing an economic co-operation as a model which does not cover certain objectives is because the countries in the area, except Turkey and Greece, have neither infrastructure, regulation, nor financial institutions ready for this kind of arrangement. 


\section{Institutional Structure of the BSEC Project with Regards to Its Goals and Formation}

\subsection{Establishment of the BSEC Project}

The first meeting on the BSEC Project was held on December, 19-21, 1990 in Ankara on the initiative of Turkey which advanced the idea of the BSEC.

In the final declaration of the conference, the official representatives of Turkey, the Soviet Union, Romania and Bulgaria affirmed the establishment of the BSEC.

Subsequent conferences were held on March, 12-13, 1991 in Bukharest, on April, 23-24, 1991, in Sofia, and finally on July, 11-12, 1991 in Moscow. As a result, the parties agreed on the text which provided the basis for their co-operation ${ }^{13}$.

On February 3, 1992, the representatives of the original parties gathered in Istanbul to sign the declaration and were joined by the new states emerging from the dissolution of the Soviet Union. Thereafter the Declaration of the BSEC was unanimously signed by all the states expect the Soviet Union which has disintegrated and eventually the Commonwealth of Independent States (CIS) which has been established. On June 24-25, 1992, the Declaration of the BSEC has been signed by heads of the governments of the member states in Istanbul, and the declaration has come into force (See the BBEC Declaration in the Appendix I).

At the signing of the declaration, the following countries became members of the BSEC: Turkey, Russian Federation, Azerbaijan, Georgia, Ukraine, Albania, Greece, Bulgaria, Romania, Moldova, and Armenia (See map of the BSEC Countries in Table I). Consequently, the BSEC with 325 million consumers compares with 340 million of the EC and with 360 million in the NAFTA (See Basic information about BSEC Countries in Table II). Also it is wealthy in natural resources and covers 20 million square kilometres. Certain states and institutions applied to the BSEC for observer status, because the BSEC has been drawing the attention of international public opinion. Observer states are Poland, Tunisia, Israel, Republic of Slovenia and Egypt.

\subsection{The Main Goals of the BSEC Project}

Main goals of the BSEC are to increase the trade volume in the region by coordinating the economic resources of member states and to promote the development of member states through widespread investments. In that sense, co-operation is to create an intergovernmental background, in the short - run, to promote an increase in trade in goods and services among the parties. In the long - run the aim is to provide the free movements of persons, of goods, of capital, and of services and to 


\section{Table I - Member Countries of BSEC}

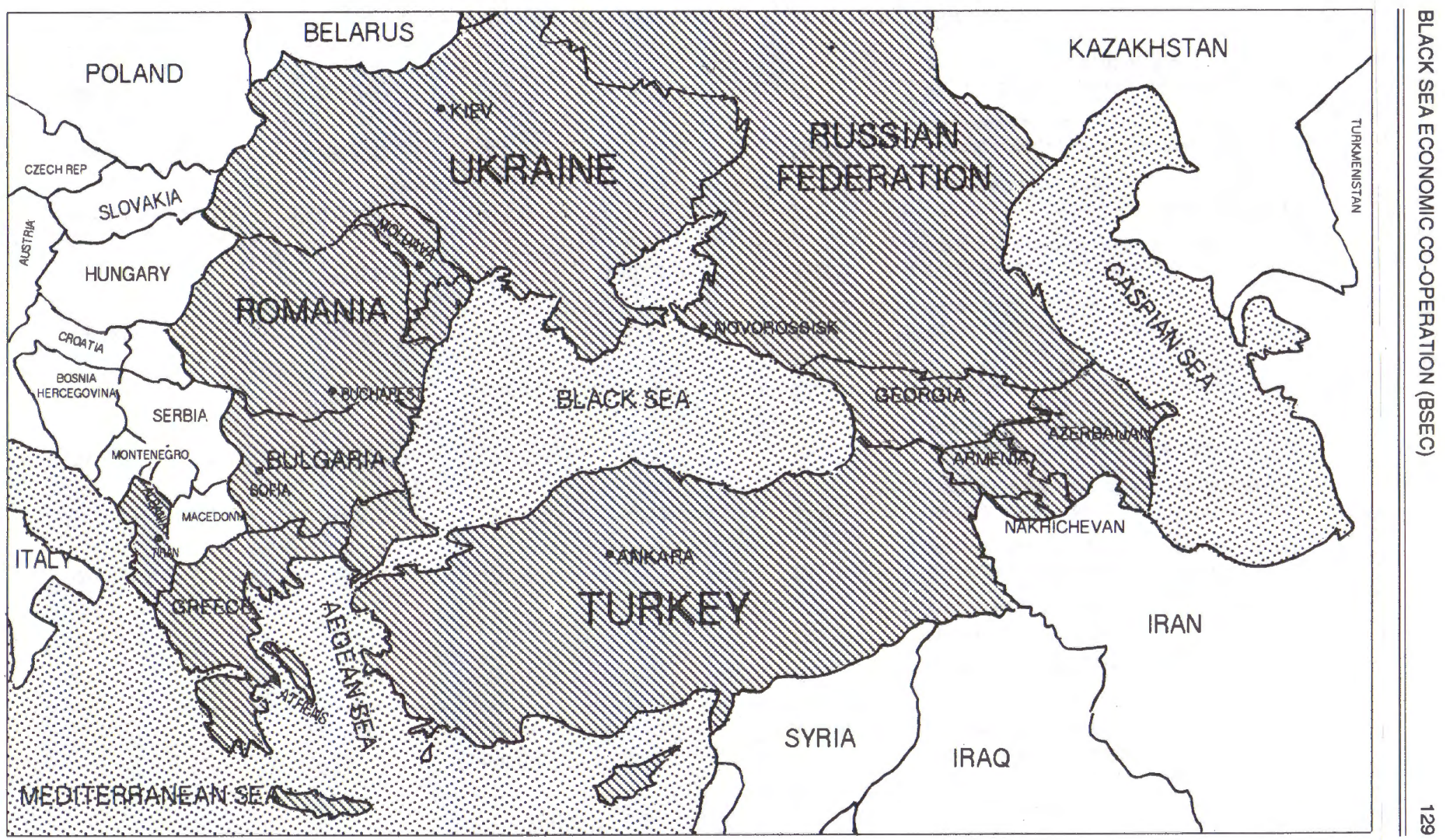


Table II : Basic Information (1991)

\begin{tabular}{|c|c|c|c|c|c|}
\hline & $\begin{array}{l}\text { Area } \\
(\mathrm{sq} . \mathrm{km})\end{array}$ & $\begin{array}{l}\text { Population } \\
\text { in Million }\end{array}$ & $\begin{array}{l}\text { Population } \\
\text { Growth (\%) }\end{array}$ & $\begin{array}{l}\text { Urban } \\
\text { Population (\%) }\end{array}$ & $\begin{array}{l}\text { Natural Resources and } \\
\text { Economic Activity }\end{array}$ \\
\hline Albania & 28.748 & 3.3 & 1.8 & 74 & Chrome, coal, oil cement, textiles \\
\hline Armenia & 29.800 & 3.3 & 0.15 & 68 & $\begin{array}{l}\text { Light industry, food processing, } \\
\text { textiles, leather, machinery }\end{array}$ \\
\hline Azerbaijan & 86.600 & 7.2 & 1.6 & 54 & $\begin{array}{l}\text { Oil, natural gas, coal, iron, cotton, grapes, vegetables, } \\
\text { petrochemicals, food, garment, electrical equipment }\end{array}$ \\
\hline Bulgaria & 110.910 & 9.1 & 0.08 & 67.6 & $\begin{array}{l}\text { Metals, minerals, timber, chemicals, } \\
\text { machinery, textiles, tur, leather, goods, vehicles }\end{array}$ \\
\hline Georgia & 69.700 & 5.4 & 1.7 & 56 & $\begin{array}{l}\text { Tea, citrus products, grain, mineral water, } \\
\text { alcoholic beverages, tobacco }\end{array}$ \\
\hline Greece & 131.957 & 10.2 & 0.15 & 57.7 & $\begin{array}{l}\text { Bauxite, lignite, magnesium, crude oil, marble, textiles, } \\
\text { chemicals, metals, food processing, cement }\end{array}$ \\
\hline Moldova & 33.700 & 4.4 & 0.1 & 47.5 & $\begin{array}{l}\text { Agriculture, wine \& spirits, tobacco } \\
\text { processed food, machinery }\end{array}$ \\
\hline Romania & 237.500 & 23.4 & 0.53 & 51.3 & $\begin{array}{l}\text { Oil, timber, natural gas, coal, iron ore, electricity, steel, } \\
\text { machinery, oil products, chemicals, textiles }\end{array}$ \\
\hline Russian Federation & 17.075 .400 & 148.5 & 0.4 & 74 & $\begin{array}{l}\text { Coal, oil, natural gas, iron, metals, minerals, rare metals, } \\
\text { agriculture, heay industry }\end{array}$ \\
\hline Turkey & 780.580 & 56.9 & 2.5 & 50.9 & $\begin{array}{l}\text { Chrome, copper, iron, steel, machinery, metal products, } \\
\text { cars, processed tood }\end{array}$ \\
\hline Ukraine & 603.700 & 51.7 & 0.25 & 67 & $\begin{array}{l}\text { Bitumen, coal, iron, minerals, meat and dairy industry, } \\
\text { grain, vegetables, sugar, heawy industry }\end{array}$ \\
\hline
\end{tabular}


strengthen the economic relations between member states ${ }^{14}$. The main characteristics of the BSEC are as follows:

\subsubsection{Goals and principles}

Among participating states, in the framework of friendly and good neighbourly relations, economic and social progress and free enterprise will be encouraged to ensure that the Black Sea region become a zone of peace and welfare on the basis of the principles of Helsinki Final Act and the subsequent decisions in the CSCE.

\subsubsection{Inter-governmental co-operation}

Governments of member states will first establish and develop projects in line with their common interests and then they will try to carry out these projects through public or private enterprise undertakings or companies.

Member states of the BSEC decided to develop close co-operation in the following areas: Transports and communications, informatics, exchange of economic and commercial information, statistics, energy, mining and processing of mineral row materials, agriculture and agro - industries, veterinary and sanitary protection, and environment ${ }^{15}$.

\subsubsection{Extra-governmental co-operation}

Participating states accorded an important role of individuals and private enterprise in promoting an efficient co-operation in addition to governmental endeavours and in setting up the necessary establishments. The parties also decided to ensure the necessary economic, commercial and legal arrangements to prepare a background for business environment with regards to free movements of goods, of services, and of capital ${ }^{16}$.

\subsection{Organs of the BSEC Project}

The following organs have been established under the BSEC:

\subsubsection{Permanent Secretariat}

In the beginning of the BSEC, Ministers of Foreign Affairs of member states

14 See BSEC Declaration in the Appendix 1.

15 Ibid.

16 Ibid. 
had decided to come together once a year to define the targets and major issues by setting up working groups. Then the need for a BSEC Permanent Secretariat to coordinate the economic social, and cultural relations among member states emerged. Therefore the Council of Foreign Ministers gathered in Antalya on December 10, 1992 after 6 months since the signing of the declaration had adopted a decision for the establishment of an organizational structure. The most important outcome of this conference was the establishment of the BSEC Permanent Secretariat in Istanbul ${ }^{17}$.

\subsubsection{Parliamentary Assembly of Black Sea Economic Co-operation} (PABSEC)

By the establishment of the PABSEC regional co-operation has gained an institutional structure. The chairmen of national assemblies of member - states, except Greece and Bulgaria, gathered in Istanbul on February 24-25, 1993 to join in the BSEC process by accepting house regulations, then, signed the Declaration of the PABSEC. By that declaration the PABSEC Secretariat was established in Istanbul and the first General Assembly of the BSEC Parliament has taken place in Istanbul on June 16-18, 1993. It consists of national representatives of 70 members, from member states (allocation of seats to member states in Table III).

Each member of the PABSEC is appointed by its own National Assembly for one year. Heads of National Assemblies take the chair over in the PABSEC, one year each in rotation. As a result, by the establishment of the PABSEC, the legal necessary background has been prepared to make rules in conformity with the aims and principles of the BSEC. In other words, the PABSEC has an important function to reflect the athmosphere of co-operation to the public and the assemblies of the member states. Therefore, a co-operation between national assemblies creates an useful instrument for the realization of the economic co-operation aim, ultimately, through the municipal laws to be made by National Assemblies.

Another point to emphasize is that the involvement of the BSEC in political cooperation in addition to economic relations has been accentuated by the establishment of the PABSEC. In fact, the PABSEC is not a supra - national organization and cannot make binding laws; whereas it may make certain legal regulations with the aim of giving recommendations to member states. Particularly, it may make studies in Black Sea region to promote political stability.

\subsubsection{The Black Sea Trade and Investment Bank}

The Black Sea Trade and Investment Bank was established to create a financial support to common projects and encouraging trade with third countries.

17 BSEC Secretariat, 1992, "Resolution of the Meeting of the Ministers of Foreign Affairs", Antalya, 10 December, p. 5. 


\section{Table III \\ Composition of the Assembly Based on the Demographic Criteria of the Participating States}

1st Group : Between 1 and 5 millions

Albania $\quad$.. 3.3 millions

Armenia - 3.3 millions

4

members 12

Moldova $\quad-4.4$ millions

2nd Group : Between 5 and 10 millions

Georgia - 5.5 millions

Azarbaijan - 7.1 millions

$5(4+1) \quad$ members 15

Bulgaria - 8.6 millions

3rd Group : Between 10 and 20 millions
Greece
10.3 millions
$6(4+2)$
members 6

4th Group : Between 20 and 50 millions

Romania - 23 millions

$7(4+3) \quad$ members 7

5th Group : Between 50 and 100 millions

Ukraine - 51.9 millions

$9(4+5) \quad$ members 18

Turkey $\quad$ - 56.5 millions

6th Group : 100 millions and over

R. Federation - 148.3 millions

$12(4+8) \quad$ members 12

Source: Devlet Planlama Teşkilatı (DPT), 1993, "Parliamentary Assembly of Black Sea Economic Cooperation Rules of Procedure", p. 17. 
By 1994, the bank will be capitalised at SDR 1 bn (\$1.4 bn), with a paid up capital of SDR $100 \mathrm{~m}$. The three biggest economies - Turkey, Greece and the Russian Federation - will each contribute 16.5 per cent, with smaller amounts from the others. The bank is also expected to seek funds from multilateral agencies such as the European Bank for Reconstruction and Development. The bank will promote regional projects and assist in intra - regional trade especially in capital goods. The head office of Black Sea Trade and Investment Bank is located in Selanica, in Greece, with the aim of establishing close relations with EC countries ${ }^{18}$.

\subsubsection{Common Working Groups}

Since the official establishment date of the BSEC, two years ago, activities of co-operation are now continuing or have newly started in many areas. Those are, ${ }^{19}$

- transport and communications,

- tourism,

- co-operation between managements of small and medium size businesses,

- commercial co-operation (free trade areas, foreign capital, harmonization of trade regulations)

- agricultural co-operation.

\subsubsection{Council of the BSEC}

Another remarkable attaintment of BSEC is the establishment of a Council of the BSEC which has brought together the private business sectors in the member states. The council also has its own secretariat in Istanbul which has the status of observer in inter-governmental gatherings, and it is the first of this kind to have acquired that status. Its major functions are, ${ }^{20}$

- to support the private sectors,

- to promote the business environment of BSEC in order to produce cooperation projects,

- to execute such projects,

18 Financial Times, 1993, "Black Sea bank for Thessalonika", 10 December.

19 For example, BSEC Secretariat, 1993, "Report of the Meeting of the Working Group on Trade and Industrial Cooperation", Kiev, 26-27 May;

BSEC Secretariat, 1993, "Report of the Meeting of the Working Group on Transport and Communications", Athens, 1-2 June.

Karadeniz Ekonomik Işbirliği Konseyi (KEIK), 1994, "1993 Faaliyetleri", Istanbul. 
- to provide support for the private sector through inter-governmental institutions, should their projects run into difficulties.

\section{Dealing with Difficulties}

There are obstacles of economic and political nature which have to be overcome in order to make the BSEC project succeed.

\subsection{Political Stability}

Nine of the 11 member states of the BSEC are former socialist countries which have, at present, no stable and powerfull political systems. On the other hand, it is hard to assume that BSEC is based on very strong trust among the member states. Karabagh is subject of conflict between Azerbaijan and Armenia; so is Trans Dinyester autonomous republic of Russian Federation and Moldova; and Oselya between Georgia and Russian Federation; and Crimean problem between Ukraine and Russian Federation; are the causes of the lack of trust. The several problems between Turkey and Greece should also be included. These political problems took precedence over economic problems at the signing of the BSEC Declaration on June 25, 1992. For example; Eduard Schverdnatze, being the leader of Georgia, suggested to set up a Committee of Ministers of Foreign Affairs and of Defence to consider the protection of Human Rights, religious and minority rights and he also proposed a reduction of the military forces of member states in conformity with the principles of Helsinki Final Act. This is why talking about economic development presumes too much optimism before establishing political stability and security ${ }^{21}$.

\subsection{Legislation on Trade and Finance}

The gap between commercial and financial regulations is one of the important problems of the BSEC. In the former socialist countries, laws and rules regulating market economy are not in a satisfactory state. The lack of the legal framework is at present inhibiting the investors who would be willing to go to those countries. On the one hand, the powers of the competent authorities are not clear and there are difficulties in discovering a competent authority, on the other hand. Moreover institutions of banking, insurance and exchange have not been established yet. Again the need of foreign capital for investment during the transition period to market economy has emerged ${ }^{22}$.

21 Dünya, 1992, "KElB, 11 Ülkenin Imza Koymasıyla Resmen Kuruldu", 26 June, pp. 1, 12. 


\subsection{Establishment of Statistical Data and Economic Information System}

Another difficulty investors are facing is getting information. The reason for that is the unfinished inventory of economic assets of those countries. In this connection, it is essential to establish a "Data Bank" to sustain the activities in investment and commerce and to compare the comprehensive statistical datas with each other $r^{23}$.

\subsection{Establishment of Communication and Transport}

For the increase of economic co-operation in the Black Sea region, development of transport infrastructure and modernization should be carried out in addition to expansion of the communication systems.

The studies of the Transport and Communication Working Group, undertaken in a BSEC perspective, have suggested a further step. Three telecommunication projects have been considered in this working group ${ }^{24}$. One of them is KAFOS (Bulgaria, Romania, Turkey and Moldova) and the other is ITUR (Italy, Turkey, Ukraine, Russian Federation) that will be set up in 1995.

When DOKAP, as the third project, is completed, Turkey will communicate with Azerbaijan and Central Assian Turkish Republics via Georgia. On the other hand, communications will be established among Eastern Europe, Baltic, and Balkans with Caucasia and Central Asia through these three projects.

Another development is the project of building highways and railways around the Black Sea. At the coast - line, the ports will be made better capable to link with either each other or third countries.

\subsection{Barter System}

The former socialist countries, being members of the BSEC, do not possess foreign currency to settle their foreign trade accounts. That is why the barter system has to be introduced to promote trade in the region. It is to prevent the economies of countries to grow worse in the transitional period to market economy in terms of trade relations. Particularly in the case of convertibility of the rouble and the of economic reforms, member states will keep the barter system in their both internal and external trade relations, like in the case of natural gas agreement between the Russian Federation and Turkey that is based on barter system. According to this agree- 
ment, Turkey will pay $70 \%$ of the price of the imported natural gas with other consumption commodities and goods; the rest will be paid by building services ${ }^{25}$. Thereafter, as mentioned above, barter system that is introduced under circumstances of necessity should not be considered as an alternative to free exchange of currency.

\subsection{Black Sea Trade and Investment Bank}

Need for foreign investments has become acute because of the limited resources of their BSEC countries in comparison to their projected targets. This need has given way to the establishment of the Black Sea Trade and Investment Bank which is mentioned in the BSEC Declaration with the object of boosting up regional resources. The major object of the Common Bank is to provide finance for internal and external trade and investments. The Bank will cooperate with the European Bank for Reconstruction and Development (EBRD) which will enable it to contribute to the financing of common regional projects ${ }^{26}$.

Therefore, at the establishing of the Black Sea Trade and Investment Bank, then head of EBRD Mr. Jacques Attali stated that, the Black Sea Trade and Investment Bank can be a partner to the EBRD; he also said that the EBRD will join the BSEC process as an observer. Mr. Jacques Attali also added that for the realization of telecommunication, transport, and natural gas pipeline projects, EUCs 3 billion are available ${ }^{27}$. Moreover, some of these projects should be carried out in the BSEC through the efforts of the individual BSEC countries. There is no doubt that the Asian Development Bank, established for similar purposes, will depend on the support of Western capital.

These points should be taken on board of the Black Sea Trade and Investment Bank by also drawing attention to the following:

1) Apart from Turkey and Greece, the member states being in the transitional period to market economy, have economic structure which does not enable the Bank

25 Dış Ekonomik liş̧kiler Konseyi (DEIK), 1990, "Türkiye-Sovyetler Birligii Ekonomik llişkileri", Istanbul, pp. 19-24.

26 "European Bank for Reconstruction and Development was established in 1990 by 41 parties who became its shareholders, i.e. 39 countries, the European Community and the European Investment Bank with the object of fostering the transition towards open market-orientated economics and promoting private and entrepreneurial initiative in Central and Eastern Europe. Its structure and modus operandi resembles that of the European Investment Bank. Though it is not, strictly speaking, a Community institution, the Bank reflects the Community policy towards the former Soviel-controlled countries and the Community participation in its work." Lasok, D., 1992 , "Institutional Issues: Participation in Community Institutions" Marmara Joumal of European Studies, vol. 2, No. 1-2, p. 66.

27 Cumhuriyel, 1992, "Karadeniz'de Somut Adımlar", 14 Decernber, p. 3. 
to get into the private sector. For this reason, the Bank, will mostly deal with the public sector, at least, in the beginning.

2) In addition to the above functions the Bank is required to play an active role in the barter system as a clearing house; particularly for member - states being into the transitional period to market economy in their trade relations in terms of financial and economic matters.

\subsection{Subvention Policy}

Another issue the BSEC should give priority to is the subvention policy. The government subsidies and encouragement may adversely influence the competition in trade among member states by improper allocation of resources, though it is hard to anticipate member - states to be familiar with the system of subsidies to renounce such policies. However, it seems impossible for the state - monopolist countries to pass through transition to market economy without encouragements coming from governments. This covers services and industry sectors, and structural changes in agriculture. At this point, some common decisions should also be made about subsidies in accordance with the aim of the BSEC. These subsidies are, ${ }^{28}$

- with the aim of removing imbalances between regions to promote relatively high standard of living in the region.

- for the sake of the common interests of the BSEC countries, some projects shall be encouraged.

- sector - aimed encouragements shall be made to facilitate the restructuring of any industry branch and to balance up obstacles caused by third countries which damage competition.

- small and medium size companies shall be encouraged.

- measures shall be taken to maintain the protection of the environment.

\subsection{Elimination of Monopoly}

The state - monopoly is being broken in the period of transition to market economy almost in every country, except in Turkey and Greece. A danger will appear if state monopolies turn into private sector monopolies. To make the integration to contribute to competition, member states shall enact laws to prevent restrictive practices and abuses of dominant position enjoyed by certain enterprises. 


\subsection{Furtherance of Border and Coastal Trade}

Countries adjacent to Black Sea are engaged in trade at their frontiers which is very significant for the future of the BSEC. Border trade is made between two neighbouring countries according to special arrangements and it covers regions close to borders.

In border trade, restrictions related to export and import are either eliminated or reduced. The reason which forces countries to engage in border trade is to avoid the high costs of transportation, and in this way, to gain important trade advantage. Common usage of border trade is today redominant among many developed countries in the world. For example, the USA and Canada carry timber trade at the border to avoid high cost. As the USA is exporting timber at one point of her border, timber is also imported from Canada at another point ${ }^{29}$.

Trade based on exchange and barter will enlarge the volume of border and coast trade between Turkey and the CIS that will lead to a reform of the trade regulations. In other words, it is necessary to enact laws and reform regulations to solve existed problems or problems that may come up in the future. Therefore, by the development of border and coastal trade, infrastructural establishment will be modernized like in the case of border ports. This will help the development of the private sector in the $\mathrm{ClS}$.

\subsection{Protection of the Environment}

Another form of co-operation coming into picture in the BSEC is in the environmental field which is gurdually gaining importance.

Particularly, since the millions of tones solid and liquid waste materials of establishments in the Black Sea area are being carried by rivers running into the Black Sea, the Black Sea is menanced by serious pollution. Moreover, there exists a particular danger in the Black Sea of nuclear waste materials.

It would be vain to dispute the importance of economic and social developments and of necessity of industrialization. On the other hand, setting up necessary infrastructures to prevent pollution is vital in establishing of new industries. This is so, because the establishments surroundering the Black Sea are based on old technology which caused poisoned and polluted material to run into the Black Sea. As a result, the degree of environmental pollution in the Black Sea has been higher than in any other region in comparison to countries using advanced technology. 
Moreover, rivers running from Europe to Asia bring also great quantities of industrial materials to the Black Sea. For example, the Danube itself running into the Black Sea through eight countries is bringing 80 million tones solid material per year ${ }^{30}$. Therefore, by linking Danube and the Main to each other through a channel and providing access to North Sea the waste material of Western and Central European Countries will be carried from Main to Danube and through Danube, it will be brought into the Black Sea.

In the case of nuclear waste materials 20 nuclear energy stations of CIS are located at the Black Sea coast. It is doubtful how safe those stations are in a technological sense and the method used to render these materials harmless. The negative effect of Chernobil can still be seen ${ }^{31}$. Therefore, the Black Sea faces danger to be a radio-active sea in 20 years unless some precautions are taken. According to Prof. Berkum, the nuclear-active materials coming from nuclear stations and working with old technology are running into the Black Sea ${ }^{32}$.

In general practice, these radio-active materials should have been stored; but ones the financial problems are appreciated, this method had to be prefered in the absence of controlling mechanism to measure the amount of radio-active materials carried into the Black Sea. Like in the example of the Danube, the protection of Black Sea is subject to not only the co-operation of countries in Black Sea area but also to co-operation of Eastern and Central European countries. In other words, cooperation between Black Sea Secretariat and EC is required to put the experience of environmental law of the EC into effect for the BSEC countries. Within the perspective of regional co-operation, the respect of legal rules, close co-operation, exchange of ideas, common programmes and research workshops are dependent upon the appreciation of the environment in member states rather than on legal and institutional regulations. In other words, the environmental problems cannot be solved merely legal procedures. This is so because the protection and validity of rules can only be ensured by implementing the law by administrative institutions. In accordance with their obligations, therefore, the ecological structure of Black Sea and economic development will be inter-connected.

In April 1992, just before the BSEC Declaration has been signed, Turkey, CIS, Romania, Bulgaria, and Georgia had entered into the Agreement on the Protection of Black Sea against pollution. There is no doubt that, for such a protective project, financial resources will be needed and there is a problem, particularly for the BSEC countries which have limited resources for this purpose. This is why BSEC countries 
need external resources. For example; countries in the BSEC need some $\$ 40$ billion to modernize nuclear stations in the $\mathrm{CIS}^{33}$.

It is the hard task for the BSEC Secreteriat Hence, for the control administration of environmental affairs, the BSEC should cooperate with the United Nations Environmental Programme (UNEP) and the United Nations Development Programme (UNDP) in the context of the Global Environmental Facility which provide aid in technical and financial areas to support the projects for the protection of environment. Yet, in the absence of controlling mechanism and binding common regulations that will be set up in the BSEC Secretariat, it is hard to take sensible steps for the prevention of Black Sea pollution. It would make the co-operation with the Central and Eastern European countries with regard to the Danube difficult unless the BSEC Secretariat is given the power to enact binding laws and regulations to prevent pollution.

It would be too optimistic to anticipate the member states adopting such a strong attitude in environmental matters by setting up productive establishments sensitive about environmental problems, if efforts are being made for attracting foreign capital in the atmosphere of development. Here, another point to be mentioned is the western industrial countries whose attitude is unclear whether they will transfer waste materials, including nuclear-active materials, to the Black Sea, because according to their law they should move these materials out of their territory.

\subsection{Fishery Sector}

Fishery is one of the important sources of income for mankind in Black Sea. The rapid exhaution of fish resources is often predicted by experts, because of the excessive fishing and environmental pollution ${ }^{34}$. Another point, which is also seen in EC countries, is the violation of the conservation areas. This is why some fishing boats are confiscated by warships of coastal states concerned for the reason of being in territoral waters.

For the protection of fishery and on behalf of the fishery sector, pollution of the sea, excessive fishing and violation of conservations areas should be brought to the agenda for the BSEC.

\subsection{Tourism Sector}

Tourism is seen as the economic potential in the development of the region; therefore it is inperative to make infrastructural investments, like hotels, to be able to 
attract the attention of international tourism agencies to the Black Sea for the purpose of development of the tourism sector. Again the problems is to raise adequate capital, and to remove the continuous political tension in the region which will negatively influence tourism.

As known, the development of tourism is also dependent upon protection of the nature. This is why BSEC countries should commonly struggle not only against environmental pollution, but also against destruction of nature and historical objects also damaged by the tourism sector unless conservation measures are taken. For example, Spain and Italy being South - Wing members of EC have caused destruction of the nature by tourism. This indicates the need for a common tourism policy following the experience of countries which take into consideration the presersation of natural resources in their development of tourist industry. In the future common decisious of member states in the perspective of the BSEC project will be welcome. Conjunctively, the BSEC countries hope to drive important income from this sector. Therefore, the BSEC countries are taking the issue as an important income source by paying attention to the rise of tourism.

\subsection{Oil Pipeline Project}

Multi functional co-operation between the member states of the BSEC depends on realization of common projects. Therefore, all member states have to cooperate with the BSEC and with each other. The project for carrying Azarbaijan oil to world market is a good example of this co-operation, and indeed this project might be the first important one linking all the member states of the BSEC. Azarbaijan economy is based mainly on oil resources. The availability of financial resources for the setting up and reorganization of the internal economy is indispensable for Azarbaijan to attain the world - wide market conditions.

Turkey has a great advantage in this respect as she is able to transport oil and gas to Western countries. From a geographic point of view, as a first step of this project, transportation by a pipeline to the Mediterranean port of Yumurtalık via Turkey and then by giant tankers to the world market has been discussed. There is still no decision on the contract for the pipeline. The above mentioned pipeline can run as follows (see map of oil pipelines in Table IV).

- By Azerbaijan, Armenia, and Turkey, but because of the war between Azarbaijan and Armenia it is at present impossible.

- By Azerbaijan, Georgia, and Turkey, but because of the civil war in Georgia it is at present impossible.

- Another pipeline project which can be constructed between Azerbaijan, Iran, 


\section{Table IV - Oil Pipelines}

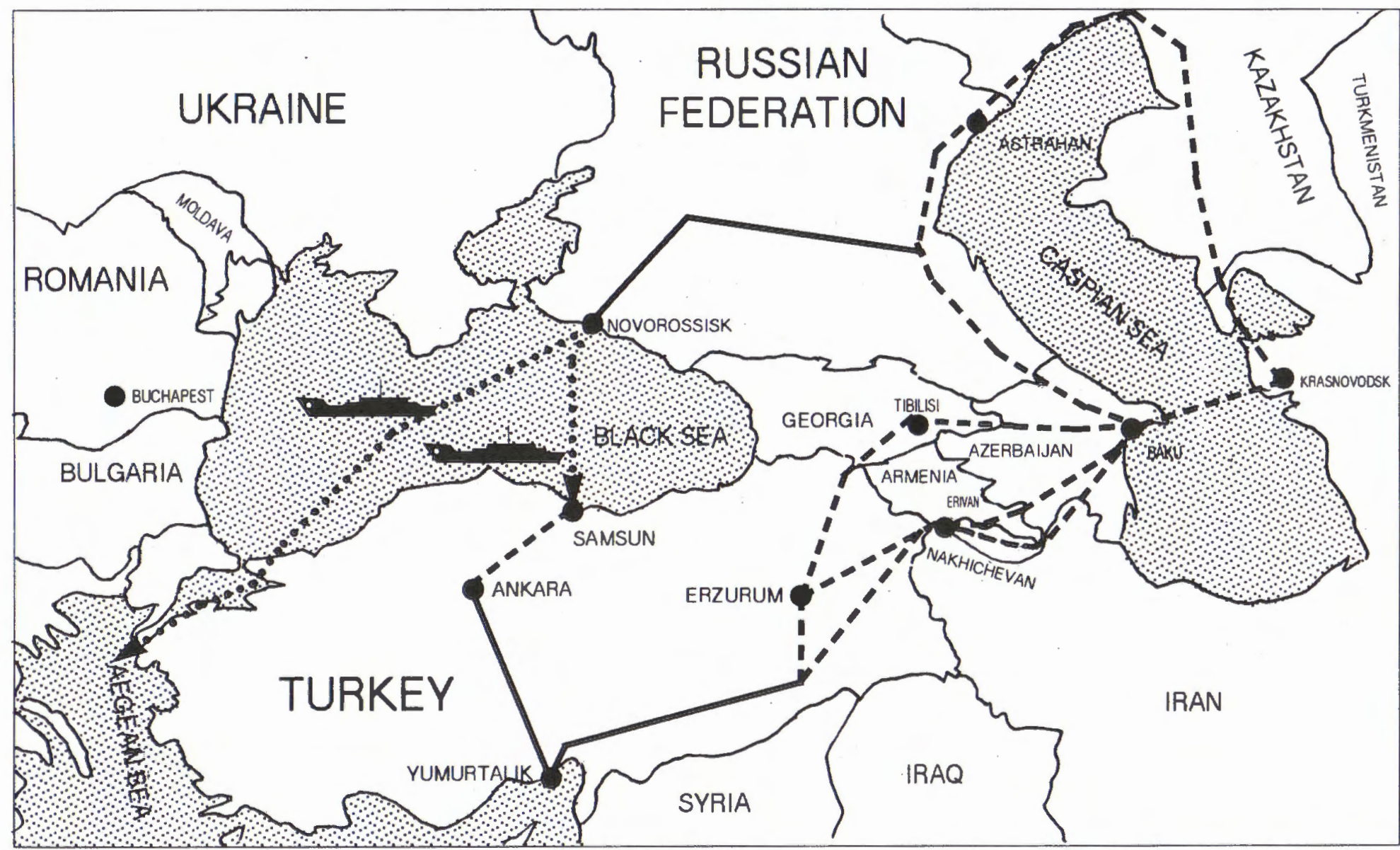

THE EXISTINGPIPELINES 
and Turkey may evoke pessimism among the countries, which are connected with that project, because of the Islamic fundamentalist regime in Iran. For example, Western countries, as financial supporters of the project would be apprehensive about depending on Iran, as the Iranien Government might close the pipeline in the future, in an event of $\mathrm{crisis}^{35}$.

- All of the three ways seem to have some problems. Therefore, an alternative may be considered. Accordingly the oil pipeline can reach the Russian port of Novorossisk by the Black Sea and then oil will be transported by tankers via Bosphorus to the world market.

Due to the safety of the Bosphorus and concern for environmental protection Turkey does not allow big tankers to pass along this waterway as they pose a potential threat to Istanbul and people who are living in visinity. If this way were used, the smallest tankers with the capacity of 120000 tonnes or the biggest of 300000 tonnes capacity would increase the traffic on the Bosphorus and Istanbul would be faced with a great danger. The last collision between the Nassia, a Greek - Cypriot registered oil tanker, and a coaster in the Bosphorus on March 13, 1994, is a warning signal ${ }^{36}$. Two alternatives for the Bosphorus option are possible if it is impossible to keep the Russian Federation out of the pipeline projects. Accordingly the oil which is transported to the Russian port of Novorossisk, instead according to the Bosphorus option:

i) can be transported to the Turkish port of Samsun at the Black Sea by tankers and then pumped into a pipeline reaching the Turkish port of Yumurtalık at the Mediterranean and then can be transported to the world market by tankers.

ii) can be carried by a pipeline under the Black Sea to the Samsun port in North of Turkey and then to the Ceyhan Port at the Mediterranean and by tankers to the world market.

Evaluating all these options, we can come to the following conclusions:

- Azarbaijan oil resources were controlled by the Soviet Union before it had collapsed. Despite of the collapse of the Soviet Union the Russian Federation still tries to keep the oil situation under its control. It is evident that, if this pipeline project can be realized without the Russian Federation, oil of the

36 The last collision in the Bosphorus left 12 crew dead and up to 16 missing. The collision, which had occurred near the Black Sea mouth of the strait and had caused an oil spill, brought home Turkey's fears over the dangers posed by increased lanker traffic through the Bosphorus, one of the world's most crowded waterways. An official at the Turkish port authorities warned that there could be large-scale pollution if the wind direction changed (Financial Times, 1994, "Pollution threat as tanker collision leaves 12 dead", 15 March). 
Central Asian Republics, which were controlled by Moscow untill a short time ago, can be transported to the world market via the same line.

- If the oil pipeline reaches Turkey through the Russian Federation, Turkey should make an effort to choose an alternative via the Bosphorus, that is, one of the mentioned pipelines between the Russian port of Novorossisk at the Black Sea and the Turkish port of Yumurtalik at the Mediterranean. Precisely, because there is no decision in this matter, Turkey ought to assume a leading role.

\section{Two things are important:}

i) Turkey should organize international conferences, like one on international environment, to enable the societies in Western countries to appreciate the importance of the environmental issue within area, especially for Istanbul with 10 million population. Such conferences are necessary because oil companies of Western countries would support the pipeline project financialy. It is important for those companies to transport oil to world market as soon as convenient; in other words, they ought to be interested in the Bosphorus option $^{37}$.

ii) Turkey also should initiate a debate of all these problems in the Parliamentary Assembly of the BSEC. This is very important for the future of the

37 Because of protest of environmentalists after the last collusion belween the Nassia and a coaster in the Bosphorus the Turkish government decided to put in order the traffic in the straits by introducing a newly-designed system. The following passage makes the problem clearer:

"Unhindered passage for all merchant ships using the waters of the Bosphorus and Dardanelles, which divide Europe and Asia, is quaranteed under the 1936 Montreux Convention. Only warships require permission of the signatory countries. This was an important control over the Soviet Union's fleet during the cold war.

Although the passage is considered dangerous with erratic currents and 12 narrow turns, it is not obligatory to take navigational pilots. The Istanbul maritime authority estimates that fewer than half of the 40,000 vessels which cross the Bosphorus each year take a pilot on board.

In the wake of the break-up of the Soviet Union, sea trade volumes have increased sharply as the Bosphorus is the most direct route to western markets for many of the newly emerging states.

Additional traffic is expected following last year's opening of the Mainz-Danube central European canal system, linking the Baltic with the Black Sea.

However, Turkey's main concern is over the threat posed by a large increase in oil cargoes if the central Asian countries choose to ship oil from new fields to western markets via the Bosphorus.

Turkey estimales that $80 \mathrm{~m}$ tonnes of crude would pass every year through the straits if the Black Sea route is used, compared with $5 \mathrm{~m}$ tonnes today. (...)

The Turkish government has raised its concerns with the Intemational Maritime Organisation, the United Nations body which handles maritime disputes. From July, Turkey will tighten rules for vessels of more than 150 metres in length, in a move clearly aimed at oil tankers. New traffic lanes, and restrictions on large vessels using the straits at night wil be introduced" (Financial Times, 1994, "Pollution threat as tanker collision leaves 12 dead", 15 March).

On the other hand, it must be said that these new rules are not sufficient to maintain and preserve the environmental security in the straits because they don't forbid oil tankers and other ships which carry dangerous materials to pass the straits. In other words, these rules may, in practice, only reduce the possibility of having such accidents in the strails, but cannot eliminate it completely. 
BSEC. Should this parliamentary body take any decision regarding the tanker access from the Bosphorus, this decision way provide some new opportunities for the regional co-operation projects.

\section{BSEC - EC Relations}

The BSEC is interested in the relations with all economic and commercial blocks, especially the European Community. The BSEC Declaration also confirms "the intention to develop economic co-operation as a contribution to the CSCE process, to the establishment of a Europe - wide economic area, as well as to the achievement of a higher degree of integration of the participating states into the world economy ${ }^{\mathrm{m} 38}$.

It is known that three of the four founder states (Turkey, Bulgaria, Romania) hope to be members of the EC. Because of their economic, social and political problems these countries may have to wait for admission to the EC for some time ${ }^{3}$.

No doubt, the EC would like to see those countries to have stability in economic, social and political fields before they are accepted to the EC. On the other hand, it is also in the interest of the EC to help the BSEC countries (except Greece and Turkey) so that they can accelerate their advance for transition to democracy and to market economy. This is necessary for an intensive joint venture between the BSEC and the EC. It is clear that the BSEC has rich natural resources whilst the EC has capital, and these elements can be combined to the advantage of both.

The EC may be in danger if the BSEC countries are unable to achieve a political and economic stability because a prolonged instability can lead to chaos forcing people to emigrate to Western countries. What can the EC do? Can the EC build a wall, like the Berlin Wall, during the "Cold War" or can the EC stop emigration by force? For example, there are about 1 million Germans in Asia. What will the German Government do, if those people decide to emigrate to Germany to escape from a civil war provoked by economic and political instability in the region?

All these questions suggest that the $E C$ ought to be interested in a intensive joint venture with the BSEC countries. The member countries of the BSEC offer three benefits for such a joint venture:

Firstly, rich natural resources,

Secondly, highly skilled people,

Thirdly, a market of with 325 million consumers. 


\section{Conclusions:}

The BSEC project, which bears the potential of changing the fate of the Black Sea basin in economic and commercial terms, was first put forth by Turkey in 1990. After a preparatory stage, the BSEC project came legally into existence by the BSEC Declaration signed in Istanbul by the Presidents of 11 member states on June 25, 1992.

The BSEC project aims at enhancing the economic and commercial cooperation between the countries in the region in the short term. Moreover, a free trade area may be established in the region in the long term. The notion of a free trade area was not included in the declaration but this initiative has been defined as economic co-operation instead. However, after an examination of the BSEC Declaration, it can be said that it aims at something more advanced than mere economic cooperation.

The problems that may come up in the running of the project may be divided in two'groups: The first include the political problems in the region. Nevertheless, the fact that a member of countries have joined together in this effort, despite the political tensions between them, should be considered as a great success. This gives hope for the future. It may also be true that with the establishment of BSEC institutions, some improvement will be achieved in the solution of political problems. The establishment of a common parliament (PABSEC) is a positive step.

The second group of problems comprise the economic ones. These problems stem from the particular conditions of the member countries, the differences in their levels of development and the problems encountered in economic integration endeavours. BSEC member countries are undergoing restructuring and try to open up to foreign markets, with the exception of Greece and Turkey. The ex-socialist countries have organized their economic structures on the basis of centrally planned economy and in the past have developed their commercial ties with the other $\mathrm{CO}$ MECON countries on a non-competitive and interdependent pattern. In addition, interstate trade has been limited to bilatered barter agreements due to the shortage of foreign exchange. The countries which are undergoing transition to market economy also aim at converting their trade to foreign exchange.

For an effective implementation of the BSEC project, the problems should be diagnosed and evaluated. The bilatered relations between the countries should be developed in a multilateral direction and common measures should be taken to ease the transition to market economy.

In the first stage, joint ventures should be initiated between the countries in the region with the aim of political stability. Unless concrete measures for the solution of 
political problems between these countries are not taken, the development of economic and commercial ties may be difficult to achieve. Therefore, member states should engage in multilateral efforts to solve the political problems and develop the economic and commercial relations between each other.

The free trade area may be initiated only after the first stage has been completed. EFTA may be taken as an example in the establishment of the free trade area which should not impinge on the responsibilities of those member states which take part in other regional integration organizations. It should be complementary to these organizations. In the second stage, new countries may become parties to the BSEC as outlined in the BSEC Declaration, for example, Central Asian Republics.

The fact that the BSEC region constitutes a large market and has important natural reserves makes the BSEC relevant to all other economic integration initiatives. It is of interest particularly to the EC since it includes East European countries. The BSEC may also serve to prevent the economic and social upheavals which may surface up in the transition to market economy. The mass immigration which may result from continuing political instability and economic problems may cause discomfort to EC countries. For these reasons, close co-operation between the $\mathrm{EC}$ and BSEC is certain to serve the interest of both parties.

The BSEC may prove to be a successful case of regional integration on the condition that the member states have faith in the viability of this initiative and work side by side in the elimination of political and economic barriers to their co-operation.

\section{Appendix 1}

\section{Declaration on Black Sea Economic Co-operation}

1. Taking into account the profound and rapid changes in Europe and the determination of the peoples of the continent to shape a new era of peace and security on the basis of the principles laid down in the Helsinki Final Act and the follow-up CSCE documents and particularly in the Charter of Paris for a new Europe,

2. Recognizing that a prosperous and united Europe will evolve on shared values such as democracy based on human rights and fundamental freedoms, prosperity through economic liberty and social justice, and equal security for all our countries,

3. Taking into consideration the potential of the participating States and the opportunities for enhancing the mutually advantageous economic co-operation arising from their geographic proximity and from the reform process and structural adjustments, 
4. Conscious of the importance of the environmental problems of the Black Sea for the well-being of their peoples and recognizing that it is vital to ensure the environmental sustainability of their economic development,

5. Confirm the intention to develop economic co-operation as a contribution to the CSCE process, to the establishment of a Europe-wide economic area, as well as to the achievement of a higher degree of integration of the participating States into the world economy,

6. Share the common objectives to achieve the further development and diversification of both bilateral and multilateral co-operation among them as well as with other intrested countries, to foster their economic, technological and social progress, and to encourage free enterprise,

7. Agree that their economic co-operation will be developed in a manner not contravening their obligations and not preventing the promotion of the relations of the participating States with third parties, including international organizations as well as the EC and the co-operation within the regional initiatives,

8. Aim to ensure that the Black Sea becomes a sea of peace, stability and prosperity, thriving to promote friendly and good neighbourly relations,

9. Declare that the economic co-operation among the participating States will be developed on the basis of the principles of the Helsinki Final Act and the decisions in the subsequent CSCE documents, as well as of the other universally recognized principles of international law,

10. Agree that the economic co-operation will be promoted gradually and, while determining the priorities in this process, they will take into account the specific economic conditions, interests and concerns of the countries involved, and particularly the problems of the countries in transition to market economy,

11. Affirm that the whole economic co-operation among their countries is open for the participation of other intrested States recognizing the provisions of this Document. As regards projects of common interest, individual countries, their economic and financial institutions, enterprises and firms as well as regional and international economic and financial institutions could be involved in their realization,

12. Decide to develop comprehensive multilateral and bilateral Black Sea economic co-operation, covering the various fields of activity as specified below,

13. Affirming their determination to make best use of all possibilities and opportunities for expanding and multiplying their co-operation in the fields of economics, including trade and industrial co-operation, of science and technology and of the environment, the participating States declare that they will take from now on concrete 
steps in this process by identifying, developing and carrying out, with the participation of their competent organizations, enterprises and firms, projects of common interest, inter alia in the following areas:

- transport and communications, including their infrastructure;

- informatics;

- exchange of economic and commercial information, including statistics;

- standardization and certification of products;

- energy;

- mining and processing of mineral raw materials;

- tourism;

- agriculture and agro-industries;

- veterinary and sanitary protection;

- health care and pharmaceutics;

- science and technology.

14. In order to promote their co-operation, the participating States will act to improve the business environment and to stimulate individual and collective initiative of the enterprises and firms directly involved, mainly by:

- facilitating, via bilateral negotiations, the prompt entry, stay and free movement of businessmen in their respective territories and encouraging direct contacts among enterprises and firms;

- providing support for small and medium-sized enterprises;

- contributing to the expansion of their mutual trade in goods and services and ensuring conditions favorable to such development by continuing their efforts to further reduce or progressively eliminate obstacles of all kinds, in a manner not contravening their obligations towards third parties;

- ensuring approriate conditions for investment, capital flows and different forms of industrial co-operation, notably by concluding and putting into effect, in the near future, agreements on the avoidance of double taxation and on the promotion and protection of investments;

- encouraging the exchange of information on international tenders organized in the participating States so as to give the opportunity to their enterprises and firms to participate therein, in accordance with the national rules and practices;

- encouraging co-operation in free economic zones.

15. The participating States will take appropriate steps, including by promoting 
joint projects, for the protection of the environment, particularly the preservation and the improvement of environment of the Black Sea, and the conservation, exploitation and development of its bio-productive potential.

16. The participating States will consider or encourage the conclusion of appropriate credit and financial arrangements at governmental and non-governmental level and will seek to mobilize funds, including through international institutions and third parties, for the purpose of expanding their mutual economic and commercial cooperation and implementing specific projects of common interest in the Black Sea. In this context, they will consider the possibilities and the ways of establishing a "Black Sea Foreign Trade and Investment Bank".

17. Meetings of the Foreign Ministers of the participating States will be convened regularly on rotation basis, at least once a year, to review progress and to define new targets. By common understanding, ad hoc and permanent working groups of experts are to be set up to propose the necessary arrangements concerning the co-operation in different fields. The participating States consider that at this stage of their co-operation it is necassary to ensure institutional flexibility. Representatives of the business community should be invited to this process so as to benefit from their practical experience.

18. Those States which commit themselves to the observance of the provisions of the present document can join, with the approval of the participating States, the whole process of co-operation. Organizations, enterprises and firms of third parties will also be given the possibility of indicating their interest in projects of common interest and, in case of agreement, of taking part in their implementation. Regional and international economic and financial institutions may also contribute in the carrying out of these projects. 


\section{References}

- Balkır, C., 1993, "Karadeniz Ekonomik Işbirliği Bölgesi (KEIB)", TÜS/AD, No. T/93,5 - 159, İstanbul.

- Bello, J. H. and Holmer, A. F., 1993, "The North American Free Trade Agreement (NAFTA)", The International Lawyer, vol. 27, №. 3, pp. $589-602$.

- Black Sea Economic Cooperation (BSEC) Secretariat, 1992, "Resolution of the Meeting of the Ministers of Foreign Affairs", Antalya, 10 December.

- Black Sea Economic Cooperation (BSEC), 1993, "Report of the Meeting of the Working Group on Trade and Industrial Cooperation", Kiev, 26 - 27 May.

- Black Sea Economic Cooperation (BSEC), 1993, "Report of the Meeting of the Working Group on Transport and Communications", 1 - 2 June.

- Black Sea Economic Cooperation (BSEC) Secretariat, 1993, "Report of the Meeting of the Working Group on Transport and Communications", Athens, 24 November.

- Bollard, A. and Mayes, D., 1992, Regionalism and the Pasific Rim, Journal of Common Market Studies, vol. xxx, No. 2, pp. 195 - 209.

- Cumhuriyet, 1992, "Karadeniz'de Somut Adımlar", 14 December, p. 3.

- Cumhuriyet, 1992, "Turkiye, Boru Hattı Köprüsü", 24 August, p. 1, 15.

- Dartan, M., 1992, "Karadeniz Ekonomik Işbirliği: Turkjye Lokomotif”, Görüş, No. 4, pp. 32 - 35.

- Dartan, M., 1992, "Azerbaycan'in Ekonomik Yapısı ve Piyasa Ekonomisine Geçiş Dönemi Sorunları", in Istanbul Sanayi Odası (ISO), Bağımsız Devletler Topluluğu ve Orta Asya Cumhuriyetleri, No. 11, pp. 86 - 93.

- De Lange, H., 1988, "Taking Stock of the EC - EFTA Dialogue", in Jamar, J. and in Jamar, Wallace, H. (eds.), EEC - EFTA More Than Just Good Friends? Proceedings of the Symposium organized by the College of Europe, 30 June - 2 July 1988, Bruges, pp. $310-321$.

- Devlet Planlama Teşkilatı (DPT), 1993, "Parliamentary Assembly of Black Sea Economic Cooperation Rules of Procedure".

- Dış Ekonomik Ilişkiler Konseyi (DEIK), 1990, "Türkiye - Sovyetler Birliği Ekonomik ilişkiler”, Istanbul.

- Dominik, L., 1992, "Institutional Issues: Participation in Community Institutions" Marmara Journal of European Studies, vol. 2, 1 - 2, pp. 55 - 71.

- Dünya, 1992, "KEIB, 11 Ülkenin İmza Koymasıyla Resmen Kuruldu”, 26 June, pp. 1, 12.

- Dünya, 1994, "BSEC and CIS", 30 March.

- EC - Commission, 1992, "Treaty on European Union", Luxembourg.

- EC - Commission, 1992, "Europe in Ten Lessons", Luxembourg.

- EC - Commission, 1993, "Europe in A Changing World - the External Relations of the European Community", Luxembourg. 
- Financial Times, 1994, "Pollution threat as tanker collision leaves 12 dead", 15 March.

- Harrison, D. and Weigel, K. G., 1993, "Customs Provisions and Rules of Origin under the NAFTA", The International Lawyer, vol. 27, No. 3, pp. 647 - 669.

- İstanbul Ticaret, 1992, "Asya - Pasifik Bölgesi Dünya Ekonomisinin Merkezi Olmaya Aday", 14 August, p. 3.

- Karadeniz Ekonomik İşbirliği Konseyi (KEIK), 1994, "1993 Faaliyetleri", İstanbul.

- Kuşoğlu, I., 1994, "Türkiye'de Sınır ve Kıyı Ticareti Uygulaması", Gümrük Dergisi, No. 8, pp. 31 - 39.

- Milliyet, 1992, "Zenginler Umudu", 9 July, p. 6.

- Milliyet, 1993, "Türk Cumhuriyetleri ve Avrasya Yatırım - Ticaret Rehberi", Özel Ek.

- Nokta, 1992, "Karadeniz ve Trakya'da Kan Kanseri Dehşet", No. 20, 17 May, pp. 42 - 48.

- Öcal, T. and Oktay, E. (eds.), 1989, “Ekonomi Sözlüğü”, Ankara.

- The Wall Street Journal Europe, 1993, "Brussels to Bulgaria: Keep Waiting", 24 November.

- Turkish Daily News, 1992, "Black Sea Summit", 25 June.

- Viya, 1992, "Bir Seminer - Bir Sorun", No. 2, İstanbul.

- Viya, 1992, "Karadeniz'de Nükleer Endişe", No. 3, İstanbul. 